\title{
Electrical resistivity measurements on Ice Stream B, Antarctica
}

\author{
S. Shabtaie and G. R. Bentley \\ Geophysical and Polar Research Center, Universily of Wisconsin-Madison, Madison, WI 53706, U.S.A.
}

\begin{abstract}
Electrical resistivity sounding using the four-electrode Schlumberger array was carried out at station $\mathrm{UpB}$ on Ice Stream B to an electrode spacing of $3 \mathrm{~km}$. Measured apparent resistivities were compared with theoretical models based on known relations between resistivity, density and temperature. Densities were measured in a pit and two coreholes; temperatures were measured in the upper $200 \mathrm{~m}$ of the ice stream and have been calculated for greater depth from an ice-stream temperature model. The resistivity, after correction for density and temperature, increases with depth down to $650700 \mathrm{~m}$. Below that is a marked decrease over the next $100 \mathrm{~m}$ or so that we correlate with the Holocene-Wisconsin transition zone. Still deeper there is an orders-of-magnitude increase to a value, in the basal ice, of $30 \mathrm{M} \Omega \mathrm{m}$ or more. This extremely high resistivity is similar to that reported for temperate glaciers and deep in the Antarctic ice sheet elsewhere. We attribute it to the destruction, by extensive metamorphism, of impurity-conduction paths at two-grain boundaries.
\end{abstract}

\section{INTRODUCTION}

A geophysical and glaciological program to study the West Antarctic ice streams that drain into the Ross Ice Shelf was begun in 1983, with initial studies on Ice Stream B. Upstream B (UpB) camp, in the middle of Ice Stream B2, one of the main branches of Ice Stream B Fig. 1), was established in November 1983.

Geophysical experiments conducted at and near $\mathrm{UpB}$ during the 1983-84 season included electrical resistivity sounding. Previous resistivity measurements at station RI, located in the flow band of Ice Stream E on the Ross Ice Shelf (Bentley, 1976; Shabtaie and Bentley, 1979, 1984), had rcvealed the existence of highly resistive ice at the base of the ice shelf with resistivity comparable to that reported for temperate glaciers (e.g. see Röthlisberger and Vögtli, 1967; Glen and Paren, 1975). Resistivity measurements were conducted on Ice Stream B partic-ularly to obtain more information about the nature of this anomaly. Electrode separations covered a large enough range $(2 \mathrm{~m}$ $3 \mathrm{~km}$ ) to study the ice stream throughout its thickness.

The field methods, data analysis and modeling techniques are similar to those previously described (Bentley, 1977; Shabtaic and Bentley, 1979, 1984, in pressa); we will not discuss them here. Here, we first calculate the resistivity as a function of depth in the ice, $\rho(z)$, to be expected from the variations of temperature and density. Then, we calculate the corresponding apparent resistivities, $\rho_{\mathrm{a}}$, and find that they do not match the observations well. We find that we must introduce additional parameters, representing other physical and chemical changes in the ice, to find a satisfactorily fitting model.

\section{MEASUREMENTS OF DENSITY AND TEMPERATURE}

\section{Density}

Densities were measured on a $21 \mathrm{~m}$ core that was extracted at $\mathrm{UpB}$ camp near the resistivity profile during the 1983-84 field season. Cores were cut into pieces $10-20 \mathrm{~cm}$ long, and the densities (Fig. 2) were calculated by measuring the length, diameter and the weight of the individual pieces. To measure densities in the uppermost layers, density-tube samples were taken from the side walls of a $2.5 \mathrm{~m}$ pit at different depths and weighed. Each plottcd density (Fig. 2) from the pit is the mean of four measurements at each depth. For densities at depths greater than $21 \mathrm{~m}$, we have taken a smooth curve through spot measurements on a $100 \mathrm{~m}$ core from a hole drilled near the center of the resistivity profile during the 1984-85 field program (Alley and Bentley, 1988).

\section{Temperatures}

Temperature measurements were made in the pit and the $21 \mathrm{~m}$ corehole on 16 and 17 January, just before and after the resistivity measurements. Temperatures in the pit were read from pre-installed thermometers; those in the $21 \mathrm{~m}$ corehole were measured at intervals of $0.5-1 \mathrm{~m}$ using a Thermometric glass thermistor sensor. The temperature profile (Fig. 3a) shows the expected mid-summer shape.

During December 1983, a string of 15 thermistor sensors was emplaced at depths between 25 and $200 \mathrm{~m}$ in a hot-water drillhole. Temperature measurements (Fig. 3b) were made in January 1985, 13 months after 


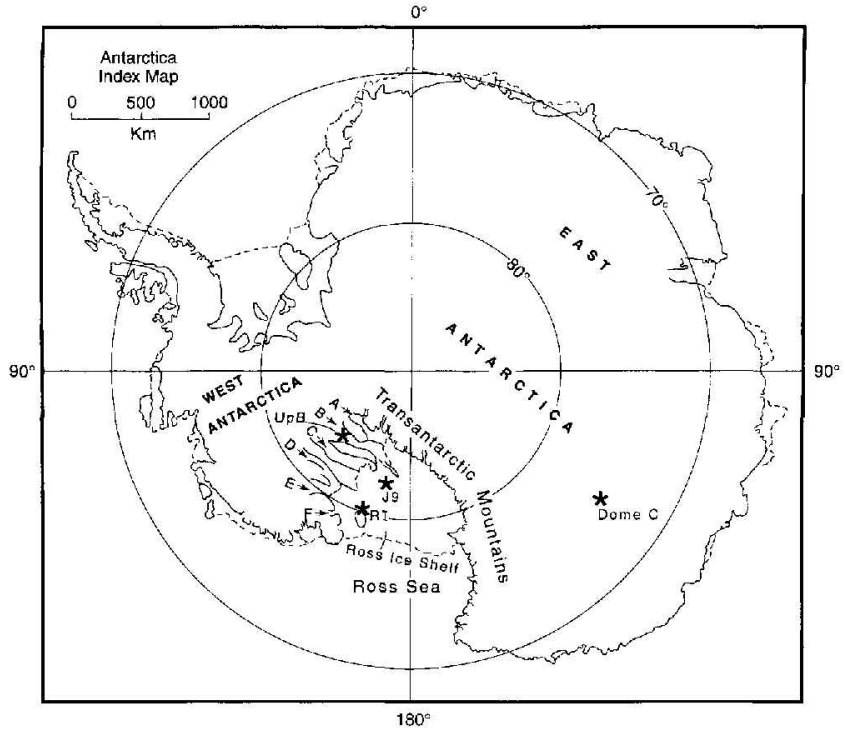

a

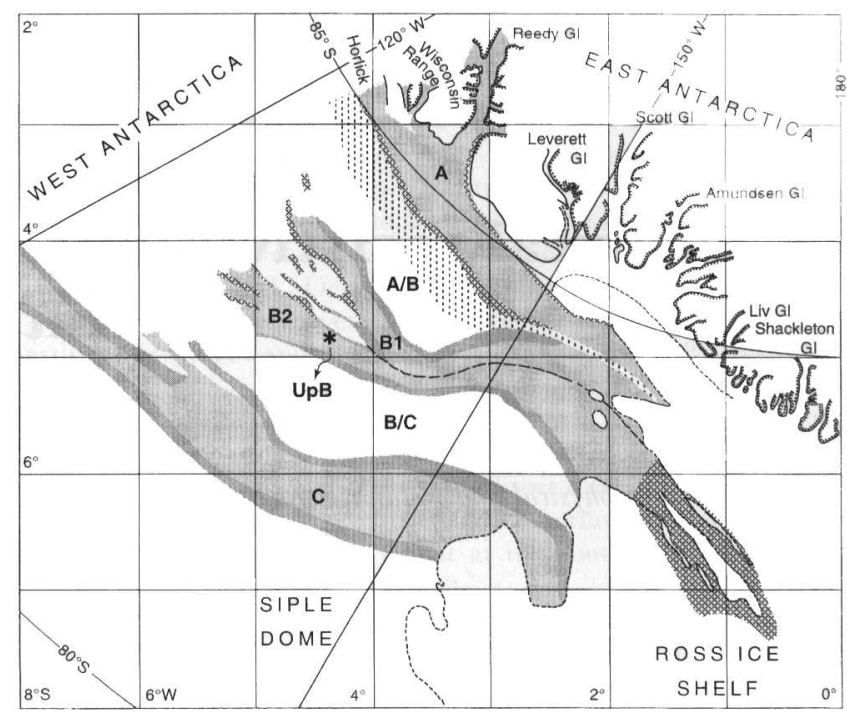

$\mathbf{b}$

Fig. 1. a. Antarctica, showing the resistivity stations discussed in the text (reproduced from Drewry (1983) with modification). b. Map of West Antarctic Ice Streams A, B and C showing the localion of UpB camp. Hachured strips denote zones of concentrated crevasses. The shorl-dashed line indicates the grounding line (junction with the Ross Ice Shelf). The long-dashed line showes the boundaries between two ice streams. For more detail, see Shabtaie and Bentley (1988).

the installation of the sensors (long enough to eliminate transient temperature changes). The temperatures show no negative gradient below the winter cold wave in the upper $10 \mathrm{~m}$, which implies that the advection of cold ice from upstream is insignificant.

T'emperatures deeper than $200 \mathrm{~m}$ were calculated from the model discussed next.

\section{TEMPERATURE MODELING}

\section{Basal boundary condition}

The temperature gradient, $G_{\mathrm{g}}$, that would be produced at the base of a stationary ice sheet by the gcothermal flux, $q_{g}$, in the absence of melting is

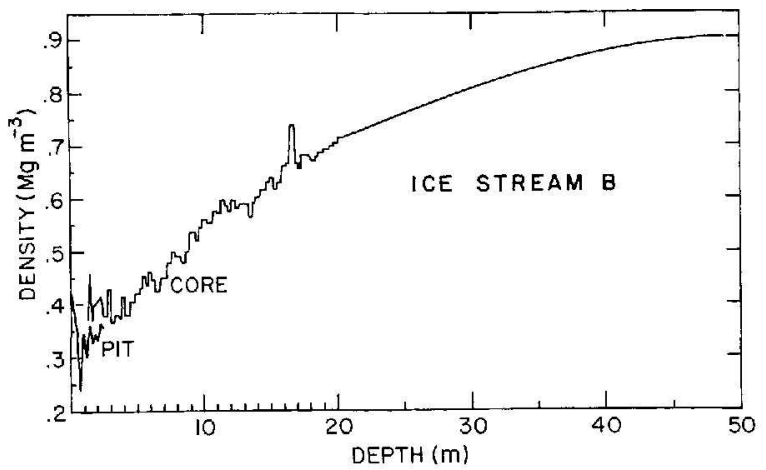

Fig. 2. Densily versus depth at UpR. The 1983-84 pit and core densities are indicated. The smooth curve at depths greater than $20 \mathrm{~m}$ shows mean densilies from the 1984-85 corehole.

$$
G_{\mathrm{g}}=\frac{q_{\mathrm{g}}}{\theta_{\mathrm{c}}}
$$

where $\theta_{c}\left(7 \times 10^{7} \mathrm{~J} \mathrm{~m}^{1} \mathrm{a}^{-1}{ }^{\circ} \mathrm{C}^{-1}\right)$ is the thermal conductivity of ice. For moving ice, the contribution from basal shear heating must be added to the geothermal heat to obtain the basal temperature gradient, $G_{\mathrm{b}}$; then, still with no melting,

$$
G_{\mathrm{b}}=G_{\mathrm{g}}+\tau_{\mathrm{b}} V_{\mathrm{b}} / \theta_{\mathrm{c}}
$$

where $\tau_{\mathrm{b}}$ is basal shear stress and $V_{\mathrm{b}}$ is the sliding velocity. (The shear-heating term in Equation (2) is independent of how the basal shear stress is accommodated by the ice sheet and its bed, so long as the heat is released near the interface.) We assume that the basal shear stress is equal to the driving stress, $\tau$, and that $V_{\mathrm{b}}$ is equal to surface velocity, $V$. These assumptions maximize both $\tau_{\mathrm{b}}$ and $V_{\mathrm{b}}$, and therefore maximize our calculated rate of strain heating. The driving stress is given by

$$
\tau=\bar{\gamma}_{i} g H \sin \bar{\alpha}
$$

where $\bar{\gamma}_{i}$ is the mean ice-column density, $g$ is the accolcration of gravity, $H$ is the ice thickness and $\bar{\alpha}$ is the surface slope averaged over a distance of $20 H$ to eliminate the effect of longitudinal stress gradients.

$\Lambda t$ Byrd Station, the assumption of a negligible basal melt rate is acceptable. The value of $G_{\mathrm{b}}$ measured in the corchole there was $0.0325^{\circ} \mathrm{C} \mathrm{m}^{-1}$ (Gow and others, 1968) and also $\tau_{\mathrm{b}} V_{\mathrm{b}} / \theta_{\mathrm{c}}=0.0065^{\circ} \mathrm{Cm}^{-1}$ (Budd and others, 1971). Equation (2) then gives $G_{\mathrm{g}}=0.026^{\circ} \mathrm{C} \mathrm{m}^{-1}$. This is close to the value of $G_{\mathrm{g}}, 0.023^{\circ} \mathrm{C} \mathrm{m}^{-1}$, given by Equation (1) for a global mean geothermal flux of $1.6 \times 10^{6} \mathrm{~J} \mathrm{~m}^{-2} \mathrm{a}^{-1}$. Lacking any better value, we initially assume $G_{\mathrm{g}}=0.026^{\circ} \mathrm{Cm}{ }^{1}$ also at $\mathrm{UpB}$. 

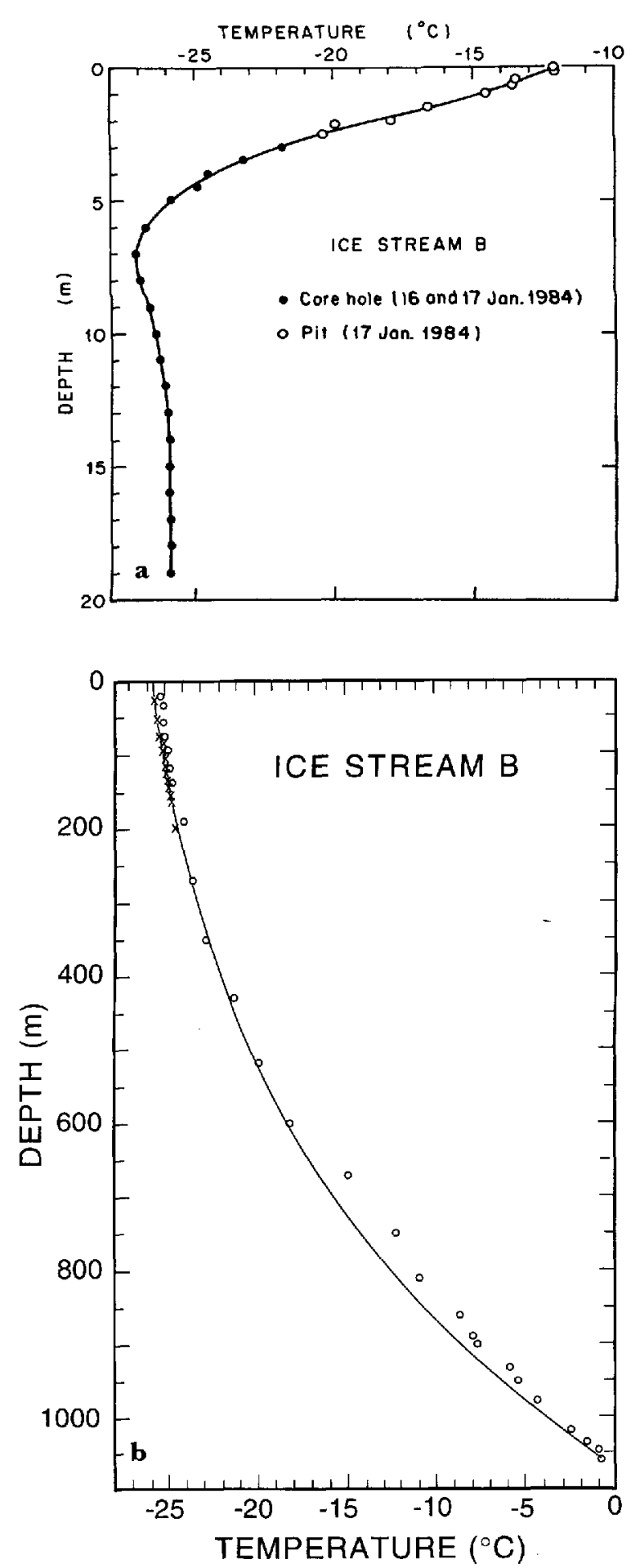

Fig. 3. Temperature versus depth at UpB. a. Temperatures in the upper $20 \mathrm{~m}$ measured in the pit and shallow corehole at $U p B . b$. Temperatures from two different hotwater drilled holes. Crosses show the measurements in the 1983-84 $200 \mathrm{~m}$ hole; circles show measurements in a hole drilled to the bed (personal communication from $H$. Engelhardt, 1993). The solid line is the temperature model described in the text.

For an ice stream, the basal melt rate, $\dot{b}_{\mathrm{H}}$, is not negligiblc, so Equation (2) is not valid; instead,

$$
\dot{b}_{\mathrm{H}}=\frac{1}{\gamma_{\mathrm{i}} L}\left[V_{\mathrm{l}}, \tau_{\mathrm{l}}+\theta_{\mathrm{c}}\left(G_{\mathrm{g}}-G_{\mathrm{l}}\right)\right]
$$

where $L\left(335 \mathrm{Jg}^{-1}\right)$ is the specific latent cnergy of fusion and $\gamma_{\mathrm{i}}\left(0.917 \mathrm{Mg} \mathrm{m}^{-3}\right)$ is the density of ice. Equation (4) is a simple generalization of an equation given by Weertman (1961). $G_{\mathrm{b}}$ and $\dot{b}_{\mathrm{H}}$ are both unknown and cannot be estimated independently, so we treat $\dot{b}_{\mathrm{H}}$ as an adjustable parameter in the heat equation. At $\mathrm{UpB}, V=440 \mathrm{~m} \mathrm{a}^{-1}$ (Whillans and others, 1987), $H=1060 \mathrm{~m}, \alpha=2.4 \times 10^{-3}$ (Shabtaie and others, 1987) and $\bar{\gamma}_{\mathrm{i}}=0.90$ (calculated from Figure 2); then $\tau_{\mathrm{b}}=\tau=22 \mathrm{kPa}$, from Equation (3).

\section{Ice-stream temperature model}

The equation of heat conduction in an ice sheet is (see Paterson, 1981, chapter 10):

$$
\frac{\partial T}{\partial t}=\theta_{\mathrm{l}} \frac{\partial^{2} T}{\partial z^{2}}-V \frac{\partial T}{\partial x}-W \frac{\partial T}{\partial z}+2 \dot{e}_{x y} \tau_{x y} / \gamma_{1} C
$$

where $T$ is the temperature, $t$ is time, $\theta_{\mathrm{d}}$ is the thermal diffusivity, $z$ is the vertical dircction (positive downward), $x$ is the horizontal direction along the flow, $y$ is the horizontal direction transverse to flow, $W$ is the vertical velocity of an ice particle, $\dot{e}_{x y}$ and $\tau_{x y}$ are the $x y$ components of strain rate and shear stress, respectively, and $C$ is the specific-heat capacity of the ice. In solving Equation (5), we assume: (a) the firn layer can be ignored, (b) horizontal temperature gradients are negligible and (c) internal strain heatings are small compared with the basal shear heating. Furthermore, we can neglect the horizontal advection term $(\partial T / \partial x)$ at $\mathrm{UpB}$, because there is such a small regional difference in mcan annual $10 \mathrm{~m}$ tcmperatures $\left(-26^{\circ}\right.$ to $-27^{\circ} \mathrm{C}, 300 \mathrm{~km}$ downstream of $\mathrm{UpB}$ on the ice shelf (Thomas, 1976 ) compared with $-24^{\circ}$ to $-26^{\circ} \mathrm{C}$, $200-300 \mathrm{~km}$ upstream (Bentley and others, 1964)) and because, as already mentioned, our temperature measurements (Fig. 3b) show that advection is not significant.

The vertical velocity $(W$ ) can be approximated by (Weertman, 1961)

$$
W=\dot{b_{0}}+\frac{z}{H}\left(\dot{b}_{\mathrm{H}}-\dot{b_{0}}\right)
$$

where $\dot{b}_{0}$ is the surface balance rate $\left(9 \mathrm{~cm}\right.$ ice $a^{-1}$ at $\mathrm{UpB}$ (Shabtaie and Bentley, 1987)). The temperature at the bed is given by the pressure-molting temperature, $T_{\mathrm{m}}$, which can be found from the Clausius Clapeyron relationship (Robin, 1976) $T_{\mathrm{In}} \approx \mu p$, where $\mu=-7.4$ $\times 10^{4}{ }^{\circ} \mathrm{C} \mathrm{m}^{2} \mathrm{~N}^{-1}$ and $p=\bar{\gamma}_{\mathrm{i}} g H$ is the hydrostatic pressure. For $\mathrm{UpB}, T_{\mathrm{m}}=-0.7^{\circ} \mathrm{C}$.

Equation (5) can be solved numerically for steady state $(\partial T / \partial t=0)$. Our procedure was to assume different values of $\dot{b}_{\mathrm{H}}$, from which $G_{\mathrm{k}}$, and $W$ could be calculated from Equations (4) and (6), respectively. The modeled temperature depth curves were then matched against the measurcd temperatures in the upper $200 \mathrm{~m}$ of the ice stream. We found for the best-fitting model $\dot{b}_{\mathrm{H}}=0.07 \mathrm{ma}^{-1}$ (the fit worsens markedly outside the rangc of $0.05<\dot{b}_{\mathrm{H}}<0.1$ ) and $G_{\mathrm{b}}=0.05^{\circ} \mathrm{C} \mathrm{m}^{-1}$ (Fig. $3 \mathrm{~b}$ ). The modeled melt rate is twice that, $0.032 \mathrm{ma}^{-1}$, gcnerated by the shear-heating term in Equation (4), even though that valuc is an upper limit. That could indicate an elevated geothermal flux or other unrecognized heat source, or it could reflect a violation of the 
assumption of steady state or of assumptions (b) or (c), all of which are questionable for such a high-energy system as an ice stream. For resistivity modcling, fortunatcly, why $T(z)$ has a particular shape is irrelevant.

Recent deep drilling at $\mathrm{UpB}$ has made it possible to obtain temperatures all the way to the bed (Engelhardt and others, 1990). The latest measurements (personal communication from $\mathbf{H}$. Engelhardt, 1993) are plotted in Figure 3b. There is satisfactory agreement for our purposes between modeled and measured temperatures, although therc is a slight offset between them decper than $600 \mathrm{~m}$ and the measured basal temperatures show fluctuations larger than would be expected so decp in the ice sheet. We have not deemed it fruitful to re-do our resistivity modeling on the basis of the measured temperatures, as we are concerned with effects far larger than those caused by the small temperature differences.

\section{RESISTIVITY}

In an ice sheet, density, temperature, impurities, crystal size and other chemical and physical properties change with depth and can or might affect the resistivity. The two parameters whose effects upon $\rho(z)$ are known are those whose determination we have already discussed, tcmperature and density. We will try to evaluate the effects of other factors from the measured resistivities.

The effect of temperature on the resistivity of both firn and solid ice is governed by the Arrhenius law with activation energy $E$ :

$$
\frac{\rho(z)}{\rho_{0}}=\exp \left[\frac{E}{k}\left(\frac{1}{T_{K}(z)}-\frac{1}{T_{0}}\right)\right]
$$

where $\rho_{0}=\rho(0)$ is the resistivity of the surface layer with temperature $T_{0}=T_{\mathrm{K}}(0), k=8.6 \times 10^{-5} \mathrm{eV} \mathrm{K}^{-1}$ (Boltzmann's constant) and $T_{K}$ is the absolute temperature. An activation cnergy of $0.25 \mathrm{cV}$ for firn and solid ice was determined from resistivity and lemperature measurements at Dome $\mathrm{C}$, on the East Antarctic plateau (Shabtaie and Bentley, in press a). That value also works well at $\mathrm{UpB}_{\mathrm{p}}$, as is shown by the modeling discussed below.

Firn can be modeled as a mixture of two components, ice and air, with volume fractions $\nu_{1}$ and $\nu_{2}$, where $\nu_{1}+\nu_{2}=1$. 'The mixture equation derived by Looycnga (1965) describes the electrical behavior of firn well. In general, Looyenga's equation gives the complex permittivity of a mixture, in terms of two component permittivities $\varepsilon_{1}$ and $\varepsilon_{2}$ :

$$
\varepsilon^{\frac{1}{3}}=\nu_{2}\left(\varepsilon_{2}^{\frac{1}{3}}-\varepsilon_{1}^{\frac{1}{3}}\right)+\varepsilon_{1}^{\frac{1}{3}}
$$

Equation (8) is symmetrical in $\nu_{2}$ and $\nu_{1}$, i.e. the result is the same regardless of whether the mixture is assumed to be ice in air or air in ice. For the d.c. limit, Equation (8) reduces to

$$
\sigma^{\frac{1}{3}}=\nu_{2}\left(\sigma_{2}^{\frac{1}{3}}-\sigma_{1}^{\frac{1}{3}}\right)+\sigma_{1}^{\frac{1}{3}}
$$

where $\sigma$ is the d.c. conductivity. For firn, $\sigma=\sigma_{\text {firn }}$, $\sigma_{1}=\sigma_{\text {icc }}, \sigma_{2}=\sigma_{\text {air }}=0$ and $\nu_{2}=1-\nu_{1}=1-\gamma_{\text {firn }} / \gamma_{\text {ice }}$, where $\gamma_{\text {firn }}$ and $\gamma_{\text {ice }}$ are firn and ice densities, respectively.
The resulting mixture equation for the resistivity of firn is

$$
\rho_{\text {firn }}=\rho_{\text {ice }}\left(\frac{\gamma_{\text {firn }}}{\gamma_{\text {ice }}}\right)^{-3} .
$$

Bentley (1977) and Shabtaie and Bentley (1979, in press b) found that Equation (10) closely described resistivities measured at several stations on the Ross Ice Shelf and at Dome C.

\section{BED RESISTIVITY}

Another parameter needed for calculating $\rho_{\text {d }}$ is the resistivity in the bed. The resistivity of wet, porous sediments, $\rho_{\mathbf{r}}$, is generally approximated by Archie's law (Archie, 1942):

$$
\rho_{\mathrm{r}}=\rho_{\mathrm{w}} a \phi^{-m}
$$

where $\rho_{\mathrm{W}}$ is the pore-water resistivity, $a \sim 1$ and $m \sim 1.5$ for most scdimentary rocks, and $\phi$ is the porosity. The resistivity we need is the mean resistivity of the upper few hundred meters of the subglacial sediments. Seismic work (Rooney and others, 1991) indicates that $600 \mathrm{~m}$ of lowvelocity $\left(\sim 2 \mathrm{~km} \mathrm{~s}^{-1}\right)$ sediment underlies the ice at $\mathrm{UpB}$, so no deeper layers need be considered. The wave velocity implies a porosity of about $30 \%$ (Blankenship and others, 1987). Using a typical ground-water resistivity of $10 \Omega \mathrm{m}$ (Shabtaie and others, 1987) leads to a resistivity of only $60 \Omega \mathrm{m}$. Measurement between two probes $20 \mathrm{~m}$ apart in the bed at $\mathrm{LpB}$, however, suggested a resistivity greater than $100 \Omega \mathrm{m}$ (personal communication from $\mathrm{H}$. Engelhardt, 1990). To be conservative, we take a high resistivity value for modeling purposes $1000 \Omega \mathrm{m}$, exccpt where otherwise noted)-adoption of a lower value would only strengthen our conclusion that the basal ice has high resistivity.

\section{APPARENT RESISTIVITY MODELS}

From the data presented in Figures 2 and 3, and Equations (7) and (10), we can calculate what $\rho(z)$ would be if it depended on $\gamma$ and $T$ alone (Fig. 4). In our numerical model, the layer thicknesses range from $0.1 \mathrm{~m}$ at the top of the ice sheet to $10 \mathrm{~m}$ at the bottom. For model $1, \rho_{\text {bedrock }}=1 \mathrm{k} \Omega \mathrm{m}$, and $E=0.25 \mathrm{cV}$. The corresponding model for $\rho_{\mathrm{a}}$, the apparent resistivity calculated by the numerical techniques discussed by Shabtaie and Bentley (in pressa), is also shown in Figure 4. The $\rho_{\text {a }}$ model fits the data for $a<40 \mathrm{~m}$ but falls much lower than the data at greater separations. This is still true even when resistivity as high as $5 \mathrm{k} \Omega \mathrm{m}$ (pure subglacial meltwater (Gow, 1968)) in the bed is assumed (Fig. 4, model 2). It is clear that the cause of the high resistivity anomaly is not a high value of the bed resistivity, so we will use a valuc of $1 \mathrm{k} \Omega \mathrm{m}$ for the remainder of this analysis.

Several models that incorporate high resistivity anomalics (in addition to the temperature and density effects) were tested; a few examples are shown in Figures 5 and 6 . The fact that modeled and measured $\rho_{\mathrm{a}}$ differ for $a>40 \mathrm{~m}$ indicates that the high resistivity 


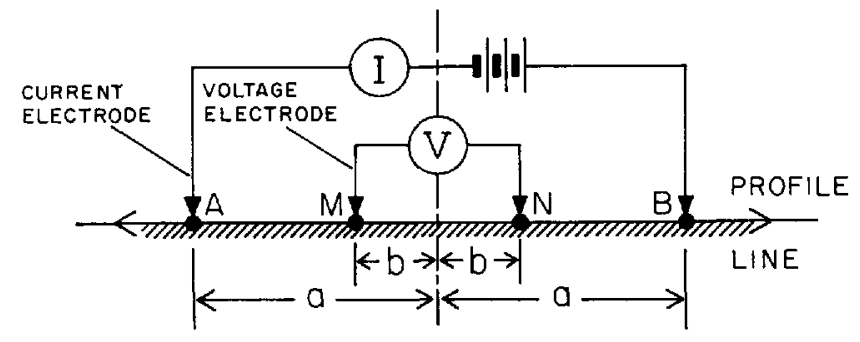

SCHLUMBERGER ARRAY CONFIGURATION

a

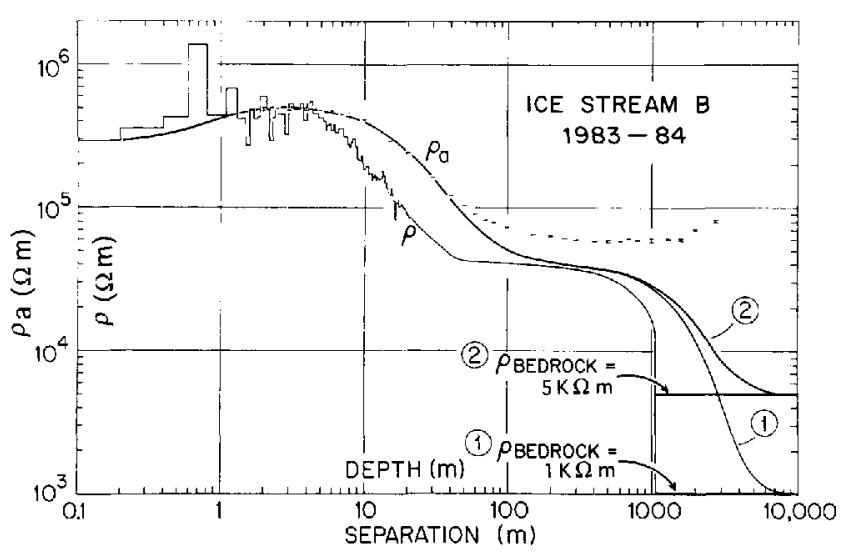

b

Fig. 4. a. Schlumberger four-electrode array configuration; $a$ and $b$ are the current and polential electrode separations (i.e. distance from the center), respectively. The apparent resistivity $\rho_{\mathrm{a}}$ for this configuration is given by

$$
\rho_{\mathrm{a}}=\frac{\pi a^{2}}{2 b}\left(1-\frac{b^{2}}{a^{2}}\right) \frac{\Delta V}{I}
$$

where $\Delta V$ and $I$ are potential difference and current, respectively. $b$. Plots of apparent resistivity, $\rho_{\mathrm{a}}$, versus electrode separation and modeled resistivity, $\rho$, versus depth. The heights of the data-point symbols represent the standard deviations of the measurements. The two models show the effects of lemperature and density only, with different assumed resistivities in the bed. The vertical and horizontal scales are the same for both $\rho_{\mathrm{a}}$ and $\rho$.

must start at a shallow depth. It is clear from model 3 (Fig. 5) that a gradual increase starting at a shallow depth will not work. What is required is an increase in $\rho(z)$ by a factor of about $1 \frac{1}{2}$, starting at about $20 \mathrm{~m}$ (Fig. 5, models 4 and 5).

An increase by several orders of magnitude in $\rho(z)$ deep in the ice is needed to produce the high $\rho_{\mathrm{a}}$ values at large separations. Modcls that include such an increasc below $800 \mathrm{~m}$ fit the data fairly well (Fig. 5, model 5; Fig. 6, model 6) but a still better fit is provided by a model in which $\rho(z)$ first decreases to a lesser value between 650 and $800 \mathrm{~m}$ (Fig. 6, models 7 and 8 ). Model 8 fits the data particularly well. Comparison of models 7 and 8 shows the sensitivity of the models changes in the position of the peak and trough in $\rho(z)$ between 650 and $800 \mathrm{~m}$ depth.

The shape of the best-fitting model (Fig. 6, model 8) is similar to the one calculated for other stations in Antarctica. Resistivity depth curves from several sites (RI, near the mouth of Ice Stream $\mathrm{E}$ on the Ross Ice

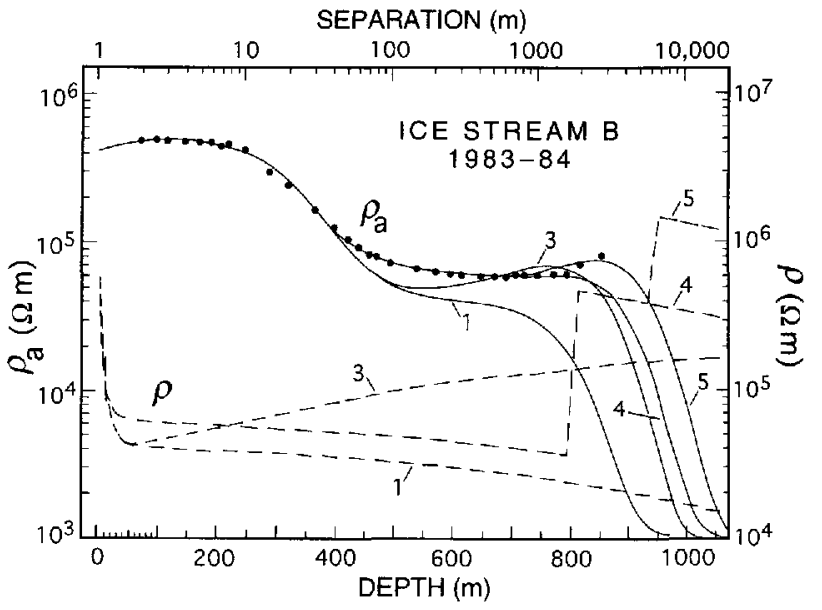

Fig. 5. Plots of modeled resistivity versus depth (dashed lines) and corresponding apparent resistivity versus electrode separation (solid lines) for models 3, 4 and 5. Model 1 is repeated for reference. Dots are the apparentresistivily data points; the diameter of the dots is equal to the largest standard deviation (the point at $a=1000 \mathrm{~m}$ in Figure 4). Note the different scales for $\rho_{\mathrm{a}}$ and $\rho$.

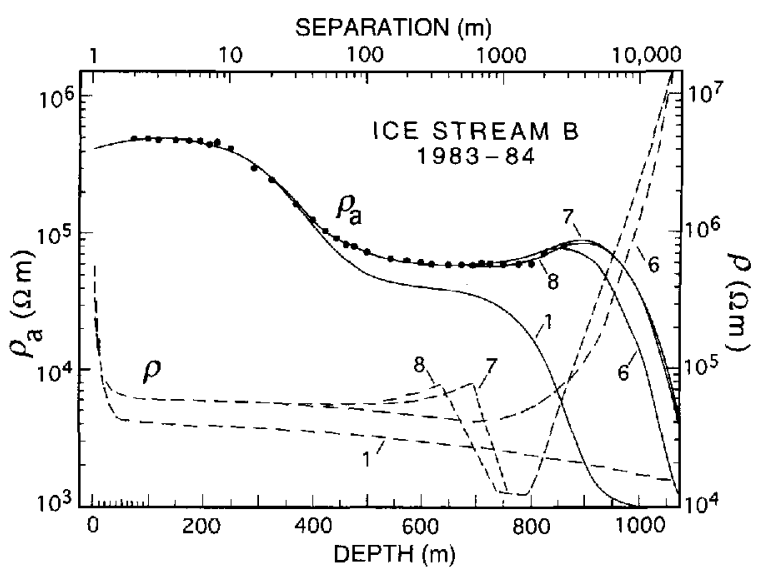

Fig. 6. Plots of modeled resistivity versus depth (dashed lines) and corresponding apparent resistizity versus electrode separation (solid lines) for models 6, 7 and 8. Model 1 is repeated for reference. Dots are the apparentresistivity data points; the diameter of the dots is equal to the largest standard deviation (the point at $a=1000 \mathrm{~m}$ in Figure 4). Nole the different scales for $\rho_{\mathrm{a}}$ and $\rho$.

Shelf; J9, also on the ice shelf (Shabtaie and Bentley, 1984, in press a)) are shown along with our model for Ice Stream B in Figure 7. In general, the profiles show similar features; exceptions are the sharp increase in $\rho(z)$ at shallow depth on the UpB profile and the absence at J9 of the order-of-magnitude increase in the basal ice.

The analyses for station J9 (Shabtaie and Bentley, 1984) and Dome $\mathrm{C}$ (Shabtaie and Bentlcy, in press a) show that variation of $\rho(z)$ with depth does not correlate with salts, sulfates, acids or any other impurities found in the chemical analysis of ice cores from those sites. Instead, changes in $\rho(z)$ are highly correlated with crystal-size variation. For example, at Dome $\mathrm{C}$ both resistivity and crystal-size increase between 90 and $400 \mathrm{~m}$, and below 


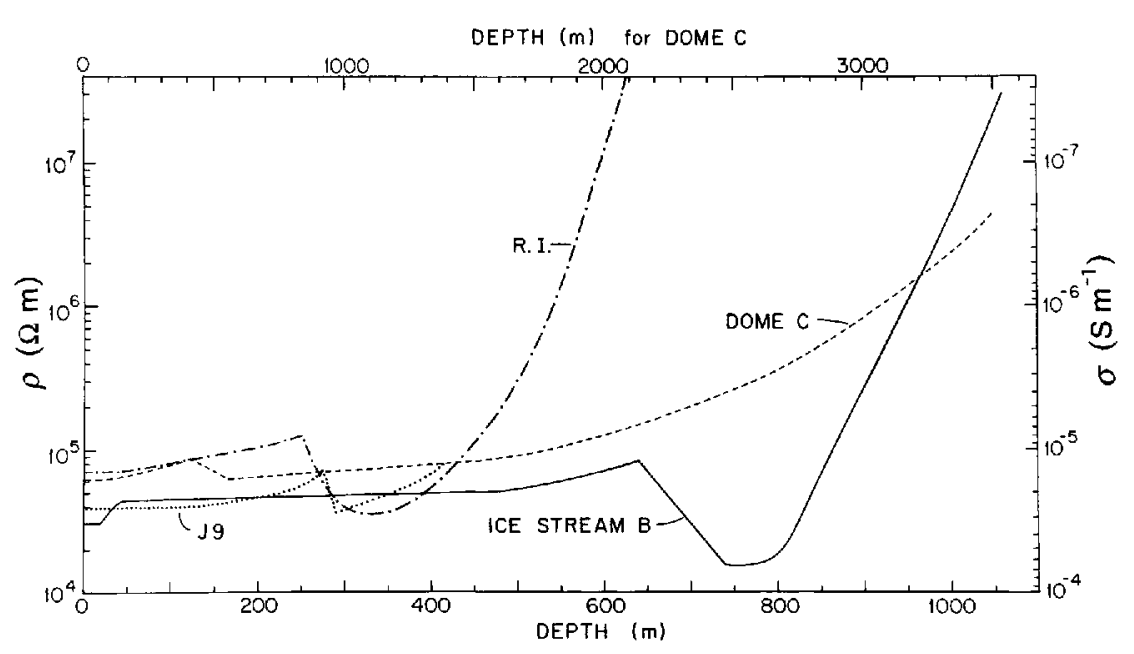

Fig. 7. Best-fitting models of resistivity (or conductivity) versus depth, corrected to solid-ice density and a temperature of $20^{\circ} \mathrm{C}$, at four Antartic locations.

$540 \mathrm{~m}$; in betwcen, in the Holocene Wisconsin transition zone, both decrease markedly. This correlation is also found clscwhere (Shabtaic and Bentley, 1984). Furthcrmore, the shape of $\rho(z)$ at $\mathrm{UpB}$ correlates well with crystal-size variation at Byrd Station (Gow and Williamson, 1976). By analogy, therefore, we conclude that the Wisconsin- Holocene transition zone at $\mathrm{UpB}$ is at a depth between 650 and $800 \mathrm{~m}$.

\section{ELEGTRICAL GONDUGTIVITY BEHAVIOR OF POLAR ICE}

It has long been known that resistivities in polar ice sheets are two or three orders of magnitude lower than in temperate and laboratory ice (see Glen and Paren, 1975; Bentley, 1977; Shabtaie and Bentley, 1979, 1984). The resistivities we have obtained from mcasurements at 13 locations on the East and West Antarctic inland ice and on the Ross Ice Shelf (Shabtaie and Bentley, 1979; work in progress by S. Shabtaie and measurements elsewhere in the Arctic and Antarctic (Meyer and Röthlisberger, 1962; Ostrem, 1967; Glen and Paren, 1975) all show this for the upper layers of the ice sheet. In decp polar ice, however, in both East and West Antarctica, the range of the resistivity values is close to that of temperate ice, although the temperatures are well bclow freczing.

Fitzgerald and Paren (1975) found that the electrical behavior of polar ice samples changed after melting and refreezing to that of temperate or pure ice. Glen and others (1977) proposed that temperate glaciers are purificd by the flushing out of intcrstitial impurities by percolating meltwater. But phenomena that require melting cannot explain high resistivities in deep polar ice that has always been frozen. Furthermore, field measurements both in the Arctic (Vögtli, 1967) and in the Antarctic (Reynolds, 1982), in zones where there is surface melting and refrcczing, yiclded resistivities that are typical of polar ice rather than temperate ice.

It is possible that soluble impurities are incorporated substitutionally into the ice lattice and that the concentration of these impurities affects the defect population, thus changing the resistivity of the ice. Laboratory measurements on monocrystalline ice doped with HF, HCl and NaCl (Camplin and others, 1978; Gross and others, 1978) have shown resistivities comparable with those in polar ice. However, the required impurity concentrations are much higher than the levels found in polar-ice samples: 8-50 $\mu \mathrm{M}$ of $\mathrm{HF}$ (Camplin and others, 1978) and 3-40 $\mu \mathrm{M}$ of HCl or NaCi (Gross and others, 1978) compared with impurity levels in polar ice sheets that range from less than $1-3 \mu \mathrm{M}$ (Delmas and others, 1980; Petit and others, 1981; Herron, 1982; I.egrand and Delmas, 1988). Furthermore, there is no corrclation betwecn mcasured near-surface resistivities (corrected to solid-ice density and $20^{\circ} \mathrm{C}$ ) and salt concentration in the form of $\mathrm{Na}^{+}$(Boutron and Lorius, 1977; Herron and Langway, 1979) for our Antarctic sites (Fig. 8). Resistivity modeling based on measured variations of salt impurities with depth at J9 (Shabtaie and Bentley, 1984) and Dome C. (Shabtaic and Bentlcy, in press a) also failed to match the measured values. Although measurements in a few decp holes in both the

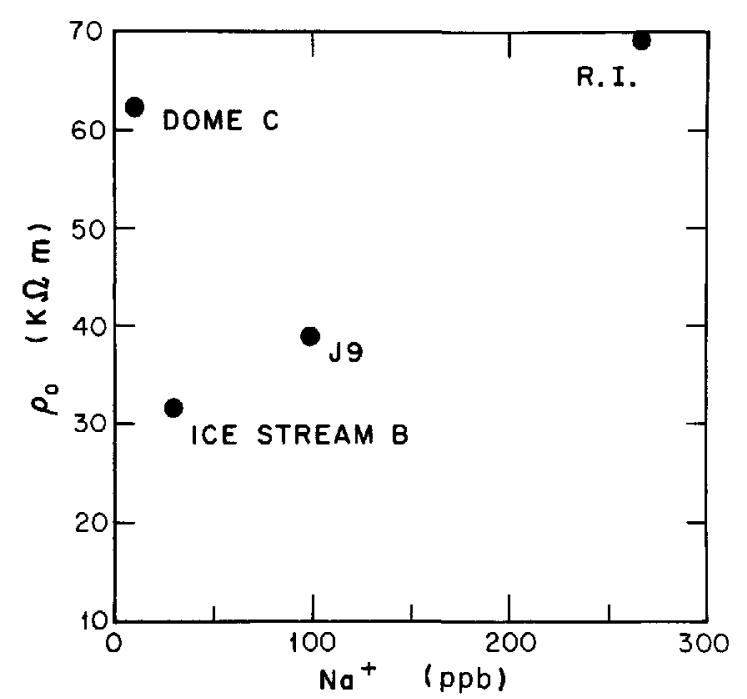

Fig. 8. Near-surface resistivity, corrected to solid-ice density and a temperature of $-20^{\circ} \mathrm{C}$, versus salt concentration at four Antarctic stalions. 
Arctic and the Antarctic confirm the existence of impurities throughout the ice column, the impurity concentrations in temperate glaciers, which are found relatively close to industrial centers and/or deserts, are up to an order of magnitude larger than in polar ice (Tagenbach and others, 1988). Clearly, the cause of the very low conductivities in temperate and some polar icc cannot be related to impurities alone; some other factor or factors must come into play.

\section{NEW MODEL}

At several locations, we have observed a strong correlation between conductivities and crystal size (Shabtaic and Bentley, 1984, in press a). An explanation for this is found in a theoretical model (unpublished work of $S$. Shabtaie) in which the impurities surround the ice grains like shells. The impurity coatings must already exist at very shallow depth to explain electrical conduction in near-surface low-density snow (Shabtaie and Bentley, 1990, in press b).

Near the surface, the grains are about $1 \mathrm{~mm}^{2}$ in sizc and are ellipsoidal in shape. However, both melting and deformation at high stresses cause extensive recrystallization and crystal growth in the ice. In temperate glaciers and deep in polar ice sheets, crystals can reach over $100 \mathrm{~cm}^{2}$ in size and are no longer convex in shape; they twist, fold and surround other crystals and become "interlocking" (Rigsby, 1968; Gow, 1970). In our model, this transformation and recrystallization effectively breaks the continuity of the impurity shells surrounding the ice crystals - it is the connectivity of the system that controls the conduction. Breaking the conducting paths does not mean removing the impurities from the system, only disconnecting them. Moderate concentrations of impurities in temperate ice and deep polar ice are accommodated by locating them in isolated domains at grain boundaries.

We believe this new model can explain conduction phenomena throughout an ice sheet. Quantitative details have been worked out for snow and firn by Shabtaie and Bentley (in press a) and for solid ice in a manuscript soon to be submitted.

\section{CONGLUSIONS}

A detailed resistivity profile was completed on Ice Strcam $B$ at separations from $2 \mathrm{~m}$ to $3 \mathrm{~km}$. Resistivities were modeled as a function of depth using measured densities and temperatures, and functional relations that are now well known. Fits were good only in the uppermost part of the ice shect; bclow that, model fitting required a $50 \%$ increase in resistivity at a depth of only about $20 \mathrm{~m}$ and an increase by at least two orders of magnitude in the bottom $200 \mathrm{~m}$ or so. A five-fold decrease in resistivity between 650 and $850 \mathrm{~m}$ was also suggested; by analogy, we associate this with the Holocene-Wisconsin transition zone. We propose that the principal fealures of the resistivity depth profile can be explained by the degree of connectedness between impurities lying on two-grain boundaries. In particular, we believe that the high resistivity at large depth arises because the extensive recrystallization and grain growth at those depths destroy the connectivity of the two-grain-boundary conduction paths.

\section{AGKNOWLEDGEMENTS}

Special thanks are due to PICO personnel (B. Koci, J. Anderson and B. Boller), who drilled the $200 \mathrm{~m}$ hotwater hole. Other individuals who assisted with different aspects of the experiment are J. Dollman, K. C. Taylor, B. R. Weertman and J.E. Nyquist. The field program was supported by U.S. National Science Foundation grant DPP-81-20332. 'This is contribution 546 of the Geophysical and Polar Research Center, Lniversity of Wisconsin-Madison.

\section{REFERENCES}

Allcy, R. B. and C. R. Bentley. 1988. Icc-rore analysis on the Siple Coast of West Antarcica, Ann. Glaciol, 11, 1-7.

Archie, G. E. 1942. The electrical resistivity $\log$ as an aid in determining some reservoir characteristics. Trans. AMME, 146, 54-62.

Bentley: G. R. 1976. High electrical resistivity deep in Antarclic shelf ice of ice stream origin. EOS, $\mathbf{5 7}(4), 243$.

Bentley, C. R. 1977. Electrical resistivity measurements on the Ross Ice Shelf. 7. Glaciol., 18(78), 15-3.5.

Bcntlcy, C. R., R. 1. Cameron, C. Bull, K. Kojima and A.J. Gow. 1964. Physical chatracteristics of the Antarctic ice sheet. Antartic Map Folio Series, No. 2. New York, American Geographical Socirty.

Blankenship, D. D., C. R. Bentley, S. 'l' Rooney and R. B. Alley, 1987. Till beneath Ice Stream B. I. Properties derived from seismic travel times. J. Geophys. Re.5., 92 (B9). 8903-8911.

Boutron, $C$. and $C$. Lorius. 1977. 'Trace element content in East Antarctic snow samples. Intemational Association of Hydrological Sciences Publication 118 Symposium at Grenoble, 1975 Isotopes and impurities in snow and ice), 164-171.

Budd, W.F., D. Jenssen and L. Radok. 1971. Derived physical characteristics of the Antarctic ice sheet. ANARE Interim Reports Series A (IV) Glaciolog), 120.

Camplin, G. C., J. W. Glen and J.G. Paren. 1978. Theoretical models for interpreting the dielectric behavior of $\mathrm{HF}$-doped ice. \% Glaciol, 21 85$), 123-141$.

Delmas, R.J., J. M. Ascencio and M. Legrand. 1980. Polar ice evidence that atmospheric $\mathrm{CO}_{2} 20,000 \mathrm{yr}$ BP was $50 \%$ of present. Nature, 284 5752$), 155-157$.

Drewry, D.J., ed. 1983. Antartica: glaciological and genphysical folio. Cambridge; University of Cambridge, Scotl Polar Rescarch Institute.

Engelhardt, H., N. Humphrey, B. Kamb and M. Fahnestock. 1990. Physical conditions at the base of a fast moving Antaretic ice strcam. Science, 248 4951$), 57-59$.

Fitzgerald, W.J. and J.G. Paren. 1975. The dielectric properties of Antarctic ice. J. Claciol., 15(73), 39-48.

Glen, J. W. and J.G. Paren. 1975. 'The clectrical properties of snow and ice. , J. Glaciol, $15(73), 15-38$.

Glen, J.W., D. R. Homer and J.G. Paren. 1977. Water at grain boundaries: its role in the purification of temperate glacier ice. International Associalion of Hydrological Sciences Publication 118 (Symposlum at Grenoble, 1975 Isotopes and impurities in snoze and ice), $26.3-271$.

Gow, A.J. 1968. Electrolytic conductivity of snow and glacier ice from Antarctic and Greenland. $\ddot{j}$. Geophys. Res., 73(12), 36433649.

Gow, A.J. 1970. Deep core studies of the crystal structure and fabrics of Antarctic glacier ice. CRREL Res. Rep. 282.

Gow, A.J. and T. Williamson. 1976. Rheological implications of the internal structure and crystal fabrics of the West Antarctic ice sheet as revcaled by decp core ctrilling at Byrd Station. Geol. Sio. Am. Bull., 87 (12), 1665-1677.

Gow, A.J., H. T. Ueda and D. E. Garfield. 1968. Antarctic ice sheet: preliminary results of first core hole to bedrock. Science, $\mathbf{1 6 1}$ (3845), $1011-1013$

Gross, G. W., I. C. Hayslip and R. N. Hoy. 1978. Electrical conductivity and relaxation in ice crystals with known impurity content. J. Glaciol., $21(85), 143-160$. 
Herron, M. M. 1982. Impurity sources of $\mathrm{F}^{\cdots}, \mathrm{Cl}, \mathrm{NO}_{3}$ and $\mathrm{SO}_{4}{ }^{2+}$ in Greenland and Antarctic precipitation. 7. Geophys. Res, 87(C4), 3052-3060

Herron, M. M. and C. C. Langway, Jr. 1979. Dating of Ross Ice Shelf cores by chemical analysis. J. Glaciol., 24(90), 345-357.

Lcgrand, M.R. and R.J. Delmas, 1988. Soluble impurities in four Antarctic ice cores over the last 30,000 years. Ann. Glaciol, 10 , $116-120$.

Looyenga, M. 1965. Dielectric constants of heterogeneous mixlure, Physica. 31(3), 401-406.

Mever, A. U. and H. Röhlisberger. 1962. Eilectrical DC resistivity measurement on glacier ice near Thule, Greenland. CRREL Tech. Rep. 87.

Ostrem, G. 1967. Laboratory measurements of the resistivity of icc. 7. Glaciol., 6(47), 643-650.

Paterson, W.S. B. 1981. The physics of glaciers. Second edition. Oxford, etc. Pcrgamon Press.

Petit, J. R., M. Briat and A. Royer. 1981. I ce age aerosol content from

- East Antarctica ice core samples and past wind strength. Nature, $293(5831), 391394$.

Rcynolds, J. M. 1982. Electrical resistivity of George VI Ice Shelf, Antarctica, Antarctic Peninsula. Am. Glaciol, 3, 279-283.

Rigsby, G.P. 1968. The complexities of the three-dimensional shape of individual crystals in glacier ice. J. Glaciol., 7(50), 223251.

Robin, G. de Q. 1976. Is the basal ice of a tempcratc glacier at the pressure melting point? .f. Glaciol., 16 (74), 183-196.

Rooncy, S. T., D. D. Blankenship, R. B. Alley and C. R. Bentley. 1991. Seismic reflection profiling of a sediment-filled graben bencath icc stream B, West Antarctica. In Thomson, M. R. A., J. A. Crame and $\mathrm{J}$.W. Thomson, eds. Geological enolution of Antarctica. Cambridge, Cambridge University Press, 261-265.

Röthlisberger, H. and K. Vögtli, 1967. Recent d.c. resistivity sounding on Swiss glacicrs. 7. Glaciol., 6 47 ;, 607621.

Shabtaie, S. and C. R. Bentley. 1979. Investigation of bottom massbalance rates by electrical resistivity soundings on the Ross Ice Shelf, Antarctica. 7. Glaciol., 24(90), 331-343.
Shabtaie, S. and C.R. Bentley. 1984. Probing the Holocene-Wisconsin boundary in polar ice sheets. Ann. Glaciol. 5, 230233.

Shabtaie, S. and C.R. Bentley. 1987. West Antartic icc streams draining into the Ross Icc. Shelf: configuration and mass balance. 7. Geophys. Res., 92(B2), 1311-1336.

Shabtaie, S. and C. R. Bentley. 1988. Ice-thickness map of the Hest Antarctic ice streams by radar sounding. Ann. Glaciol., 11, 126-136.

Shabtaic, S. and C. R. Bcntlcy. 1990. Acid snow deposited in northern ice caps beginning the industrial age. EOS, 71/43), 1314.

Shabtaie, S. and C. R. Bentley. In press a. Elcctrical resistivity sounding of East Antarctic ice shee1. 7. Geophys. Res

Shabtaie, S. and C.R. Bentley. In press b. Unified theory of electrical conduction in firn and ice. Part I: Site percolation and conduction in snow and firn. 7. Geophys. Res.

Shabtaie, S., I. M. Whillans and C. R. Bentley. 1987. The morphology of ice streams $A, B$, and $C$, West Antarctica, and their environs. 7.Geophys. Res., 92(B9), 8865-8883.

Thomas, R. H. 1976. The distribution of $10 \mathrm{~m}$ temperatures on the Ross Ice Shelf. 7 . Gluciol., 16(74), $111-117$.

Vögtli, K. 1967. D.C. resistivity soundings on Devon Island, V.WY.T.. Canada. 7. Glaciol., 6(47), 635642.

Wagenbach, D., K. O. Münnich, U. Schotterer and H. Oeschger. 1988. The anthropogenic impact on snow-chemistry at Colle Gnifetti, Swiss Alps. Ann. Glaciol., 10, 183187.

Wecrtman, J. 1961. Mechanism for the formation of inner moraines found near the edge of cold ice caps and ice sheets. 7. Glaciol, 3 30), 965978.

Whillans, I. M., J. Bolzan and S. Shabtaic. 1987. Velocity of ice streams B and C, Antarctica. 7. Geophys. Res., 92 B9), 8895-8902.

The accuracy of references in the text and in this list is the responsibility of the authors, to whom queries should be addressed. 